\title{
Variation in ecosystem services across an urbanization gradient: A study of terrestrial carbon stocks from Changzhou, China
}

\author{
Yu Tao ${ }^{\mathrm{a}}$, Feng $\mathrm{Li}^{\mathrm{a}}{ }^{, *}$, Xusheng Liu $^{\mathrm{b}}$, Dan Zhao $^{\mathrm{c}}$, Xiao Sun $^{\mathrm{a}}$, Lianfang Xu ${ }^{\mathrm{d}}$ \\ a State Key Laboratory of Urban and Regional Ecology, Research Center for Eco-Environmental Sciences, Chinese Academy of Sciences, 18 Shuangqing Road, \\ Haidian District, Beijing 100085, China \\ b Chinese Academy of Forest Inventory and Planning, State Forestry Administration, 18 Hepingli East Street, Xicheng District, Beijing 100714, China \\ ${ }^{\mathrm{c}}$ Beijing Municipal Institute of City Planning \&' Design, 60 Nanlishi Street, Xicheng District, Beijing 100045, China \\ ${ }^{\mathrm{d}}$ College of Hydrology and Water Resources, Hohai University, 1 Xikang Road, Nanjing 210098, China
}

\section{A R T I C L E I N F O}

\section{Article history:}

Available online 21 May 2015

\section{Keywords:}

Carbon stocks

Ecosystem services

Urbanization

Gradient analysis

Land use and cover change

\begin{abstract}
A B S T R A C T
Ecosystem services in urban areas are regarded as multiple environmental benefits fostered by urban-rural landscapes. A wide range of ecosystem services have been largely affected by land use and cover change in urban areas, leading to significant variation of ecosystem services, such as terrestrial carbon stocks across a gradient of urbanization. Urban areas are critical for terrestrial carbon dynamics owing to both considerable amount of biomass and soil carbon stored in cities and significant losses in carbon stocks from urban land use and cover change. We used Changzhou, a typical fast-growing city in China, as a case study, and estimated biomass and soil carbon stored in land covers using the InVEST model. We also quantified gradient changes in terrestrial carbon stocks in response to urban land use and cover change along two sample transects as a function of distance from the urban center. We found that carbon densities decreased with increasing intensity of urban development. Gradient transect analyses revealed an overall trend of increasing carbon stocks from the urban center to peri-urban areas as a direct result of land use and cover change driven by policy-oriented urban planning, which led to both infilling of empty areas within the urban center and sprawling of urban land toward peri-urban areas. As recent growth trends continue, the expansion of urban land markedly decreased areas previously dominated by green open spaces, making urban land use and cover change and losses in carbon stocks an increasingly important component of regional carbon dynamics. We proposed measures to mitigate these negative effects of urbanization on carbon stocks both for densely built-up areas and for rapidly urbanizing peri-urban areas.
\end{abstract}

(c) 2015 Elsevier B.V. All rights reserved.

\section{Introduction}

Cities are dependent on the ecosystems beyond the city limits, but also benefit from internal urban ecosystems (Larondelle and Haase, 2013). The integrative concept of ecosystem services in urban areas is defined as multiple environmental benefits urban dwellers obtain from urban-rural landscapes (Radford and James, 2013). Over the past decades, the impacts of urbanization on ecosystem services extend over large areas even though urban land occupies a small proportion of the land cover matrices in most regions (Wade et al., 2009). Urban areas have been regarded as the

\footnotetext{
* Corresponding author. Tel.: +86 1062849103 ; fax: +8610 62849103.

E-mail addresses: taoyu880216@126.com (Y. Tao), lifeng@rcees.ac.cn (F. Li), liuxush@163.com (X. Liu), zhaodan718100@163.com (D. Zhao), sxdreamfree@163.com (X.Sun), lianfangx1023@163.com (L.Xu).
}

primary contributing sources for a wide range of environmental consequences at regional and global scales, particularly for carbon dioxide emissions (Seto et al., 2012). These profound changes in land use and climate have highlighted the role of ecosystem services in sustainable urban development and climate change mitigation and adaptation (Goldstein et al., 2012). Increasingly, land use policies are recognizing the importance of urbanization as a major driver of land use change across the world, and that a better understanding of how ecosystem services are provided along urban-rural gradients is crucial in the task of conserving and enhancing ecosystem services (Davies et al., 2011; Radford and James, 2013). However, there have been surprisingly few attempts and effective modeling approach explicitly to quantify the provision of multiple ecosystem services with regard to urbanization at a city-wide scale (Chan et al., 2006; Daily et al., 2009; Nelson et al., 2009; Kroll et al., 2012). The linkages between land use dynamics and ecosystem services in urban areas remain largely 
unknown, and research on spatially explicit values of ecosystem services across landscapes that might inform land use and management decisions is highly demanded (Larondelle and Haase, 2013; Qiu and Turner, 2013).

One ecosystem service that is becoming a progressively more important feature of policies to mitigate climate change, and with other potential benefits, is carbon stored in urban biomass and soil (Davies et al., 2011; Strohbach and Haase, 2012). Although these stocks are smaller than carbon emissions from consumption of fossil fuels, urban carbon reservoirs nevertheless appear to be substantial (Davies et al., 2011), making it an urgently important research issue. Carbon stocks in urban ecosystem are altered directly and indirectly by human activities (Chen and Chen, 2012; Hubacek et al., 2012; Chen et al., 2013a,b; Yang and Chen, 2013, 2014a,b). The effects of the attendant increases in urban land uses on the storage of carbon are largely unknown (Lorenz and Lal, 2009; Zhao et al., 2010a,b; Scalenghe et al., 2011; Lu et al., 2013). In the coming decades, the amount of carbon contained in human settlements will grow because urban areas are continuing to expand at an unprecedented rate (Churkina et al., 2010). Nevertheless, this rapid growth is accompanied by land use and cover change, often at the cost of a severe reduction in carbon stocks compared with the levels that previously existed in peri-urban green open spaces. This process is the main cause of decreased carbon sequestration potential in regional ecosystem. Therefore, it is essential to better understand the carbon dynamics of urban ecosystem, rather than relying on the assumption of static carbon stocks. In other words, it is not very important to account for the proportion of total carbon stocks at a regional scale that is stored in urban areas (Liu and Li, 2012); instead, it is necessary to quantify gradient changes in terrestrial carbon stocks in response to urban land use and cover change (Patak et al., 2006; Alberti and Hutyra, 2009; Hutyra et al., 2011b; Ren et al., 2011; Zhang et al., 2012), which is vital for understanding the effectiveness of policy implementations for preservation of carbon stocks in urban areas.

Possible variation in carbon stocks across the urbanization gradient may result from (1) variation across multiple land covers with decreasing intensity of urban development, and (2) variation within each land cover with increasing distance from the urban center. To address this issue, Hutyra et al. (2011a) established several sample transects radiating from the urban center of the western American city of Seattle and estimated aboveground biomass in different land covers and explored the relationships between biomass carbon stocks and land cover across the urbanization gradient. They found that aboveground biomass increased with decreasing intensity of urban development, but that there was no statistically significant difference within each land cover with increasing distance from the urban center. This implied that the significant increase in aboveground biomass per unit area that they observed with increasing distance from the urban center resulted mainly from changes in the distribution of land covers. Therefore, carbon stocks can be estimated based on land cover types to quantify their variation across the urbanization gradient (Turner et al., 2007; Yeh and Huang, 2009), both between the urban center and periurban areas as defined by the administrative boundaries (Radford and James, 2013) and along sample transects (Kroll et al., 2012; Larondelle and Haase, 2013).

Based on this assumption, we estimate carbon stocks for different land covers, while we do not account for their variation within each land cover distributed at different distances along the urbanization gradient. The InVEST (Integrated Valuation of Environmental Services and Tradeoffs) Carbon Storage and Sequestration model developed by the Natural Capital Project team (Daily et al., 2009; Tallis et al., 2011) is therefore applied in this study that uses maps of land use and land cover types and aggregates the carbon stored in each land cover into four basic carbon pools: aboveground biomass, belowground biomass, soil organic matter, and litter layer organic matter (Chan et al., 2006; Nelson et al., 2009; Goldstein et al., 2012; Qiu and Turner, 2013). In general, the model has been widely regarded as a spatially explicit and process-based biophysical model useful in the study of terrestrial carbon stocks and their dynamics by both its developers and users from around the world. Taking Changzhou, a typical fast-growing Chinese city as a case study, the main objectives of our research are to quantify gradient changes in terrestrial carbon stocks in response to urban land use and cover change on the basis of accurate spatial datasets and reliable estimates of urban biomass and soil carbon stocks, reveal primary driving forces, and propose measures for preserving or increasing carbon stocks in urban areas.

\section{Materials and methods}

\subsection{Study area}

Changzhou is located in southern Jiangsu Province, in the Yangtze River Delta $\left(31^{\circ} 09^{\prime} \mathrm{N}\right.$ to $32^{\circ} 04^{\prime} \mathrm{N}, 119^{\circ} 08^{\prime} \mathrm{E}$ to $120^{\circ} 12^{\prime}$ E). Changzhou lies in flat terrain south of the Yangtze River. The climate is warm and cloudy, and is typical of the northern subtropical monsoon climate zone. The cultivated soil types in and around the city mainly comprise paddy soil, and the major vegetation types are mid-subtropical evergreen broadleaved forest and northern subtropical mixed stands of deciduous and evergreen broadleaved forests, with dominant species being Masson's pine (Pinus massoniana), China fir (Cunninghamia lanceolata), oaks (Quercus spp.), and bamboos (Phyllostachys Sieb. et Zucc.). Changzhou has undergone tremendous development since the mid-1980s, with rapid expansion of the area within its boundary from $187 \mathrm{~km}^{2}$ in the $1980 \mathrm{~s}$ to $1871 \mathrm{~km}^{2}$ by the 2000s. The study area comprises 42 townships under the jurisdiction of five municipal districts, with Tianning, Zhonglou and Qishuyan districts in the urban center (i.e., within the $187 \mathrm{~km}^{2}$-area boundary in the 1980s with a long history of urbanization), and Wujin and Xinbei districts in peri-urban areas (i.e., newly urbanizing areas outside of the 1980s-boundary).

\subsection{Data sources and classification of land use and land cover}

We used a series of Landsat TM images from 1986 to 2011 at a $30 \mathrm{~m}$ resolution, a 1:2000 topographic map and administrative maps provided by the Planning and Designing Institute of Changzhou for visual interpretation of land covers. The topographic map was used to differentiate hilly area from flat area in Changzhou. We classified typical land covers in the study area into forest land (timbered hilly area), green open spaces (vegetated flat area), urban land and water area. We conducted a kappa test using historical land use maps, ground-based reference information and random sampling to test the quality of the classification results. The kappa values averaged 0.82 for the six classified images. All of the values were greater than 0.7 , which is the minimal requirement for a satisfactory classification.

\subsection{Estimation of terrestrial carbon stocks in different land covers}

In this study, the forest inventory data collected by the Agricultural and Forestry Bureau of Changzhou provided information on the area and distribution of various types of forest in forest land and green open spaces. Biomass carbon stocks per unit area in these types of forest were derived from the results of several local studies (WDC, 2006; Zhao et al., 2010a,b; Cantarello et al., 2011). Estimated biomass carbon stocks in forest land and green open spaces were at some fixed storage level equal to the area-weighted average of reported storage levels of each type of forest within that land cover. A soil map covering the study area was also used (Nachtergaele 
et al., 2008), and we summed soil organic carbon for the upper $100 \mathrm{~cm}$ in each grid cell and averaged by land cover to estimate soil carbon stocks in forest land and green open spaces.

Urban forest patches, such as urban parks and green belts were classified as green open spaces in this study, while the urban land of Changzhou was covered by extensive impervious surfaces, on which biomass carbon stocks were negligible. To account for potential impact of urban soil sealing on soil organic carbon, we incorporated data from two recent studies (Raciti et al., 2012a; Zhao et al., 2012) to calculate revised soil carbon stocks in the urban land of Changzhou. Based on these studies, the measured carbon stocks in soils under urban land averaged about $50 \%$ of the values in forest soils at different depths. This probably resulted from removal of the topsoil during the development process and prevention of future accumulation of carbon in sealed soils, leading to both actual and potential losses in soil carbon stocks. We did not calculate carbon stored in water area, in which the InVEST model produced high uncertainty. As all estimates were drawn from empirical studies, we did not perform accuracy assessment for carbon stocks.

\subsection{Characterization of terrestrial carbon stocks across the urbanization gradient}

We characterized terrestrial carbon stocks across the urbanization gradient using three different approaches. (1) Estimate biomass and soil carbon stocks in terrestrial land covers with different intensities of urban development. (2) Compare estimated carbon stocks in the five municipal districts and 42 townships between the urban center (covering 19 townships governed by three municipal districts) and peri-urban areas (covering 23 townships governed by the other two municipal districts). (3) Conduct "moving window" analyses (using the FRAGSTATS software capable of calculating selected landscape metrics) to detect gradient changes in carbon stocks along sample transects as a function of distance from the urban center. The analyses quantified land cover pattern using the "percentage of landscape" metric (the proportion of total area occupied by a particular land cover) within the window. Several trials were performed to test the impact of window size on the metric and to improve the smoothing effect (Kong and Nakagoshi, 2006). Results with a 300-m radius window revealed fluctuations in the metric. The window moved over the whole study area, calculating the metric and returning that value to the center cell of the window and outputting a new continuous surface grid map for the metric. Based on the grid maps of the metric, carbon stocks were calculated as the area-weighted average of estimated storage levels in each land cover. Two sample transects were plotted in west-east and north-south directions from the urban center to peri-urban areas. These were also the directions experiencing dramatic expansion of urban land over the past few decades.

\section{Results}

\subsection{Estimated biomass and soil carbon stocks}

Estimated total carbon densities in terrestrial land covers decreased with increasing intensity of urban development, with average values of $78.85 \mathrm{MgCha}^{-1}$ in forest land, $73.82 \mathrm{MgC} \mathrm{ha}^{-1}$ in green open spaces, and $25.23 \mathrm{MgCha}^{-1}$ in urban land. Average carbon densities in soil organic matter ranged from 25.23 to $68.91 \mathrm{MgCha}^{-1}$ in different land covers, the greatest of the four carbon pools. Aboveground biomass was the next largest pool, with carbon densities ranging from 3.18 to $18.87 \mathrm{MgC} \mathrm{ha}^{-1}$, followed by belowground biomass (1.42-5.88 $\left.\mathrm{MgC} \mathrm{ha}^{-1}\right)$. Carbon stored in litter layer organic matter was the smallest component, ranging from 0.31 to $3.54 \mathrm{MgCha}^{-1}$.

\subsection{Terrestrial carbon stocks in the municipal districts of Changzhou}

Carbon densities in the five municipal districts decreased from 1986 to 2011 due to rapid expansion of urban land, which encroached on areas previously dominated by green open spaces. Carbon densities in Tianning, Zhonglou and Qishuyan districts in the urban center averaged $60.59 \mathrm{MgCha}^{-1}$ in 1986 and $32.66 \mathrm{MgCha}^{-1}$ in 2011, smaller than the values in Wujin and Xinbei districts in peri-urban areas $\left(72.64 \mathrm{MgCha}^{-1}\right.$ in 1986 and $52.87 \mathrm{MgC} \mathrm{ha}^{-1}$ in 2011) (Fig. 1a). Total carbon stocks in the three municipal districts in the urban center $(0.32 \mathrm{TgC}$ in 1986 and $0.11 \mathrm{Tg} C$ in 2011) were much smaller than total carbon stored in the other two municipal districts in peri-urban areas $(7.50 \mathrm{Tg} C$ in 1986 and $2.41 \mathrm{Tg} C$ in 2011) because carbon densities (per unit area) and area of the urban center were both smaller than the values of peri-urban areas. Decrease in carbon densities from 1986 to 2011 averaged from 1.03 to $1.19 \mathrm{MgCha}^{-1} \mathrm{yr}^{-1}$ in the urban center and from 0.70 to $0.88 \mathrm{MgC} \mathrm{ha}^{-1} \mathrm{yr}^{-1}$ in peri-urban areas (Fig. 1b), while total decrease in carbon stocks was only $0.01 \mathrm{TgC}^{-1}$ in the urban center, and in contrast with the density results (per unit area), was smaller than the values of $0.03-0.09{\mathrm{Tg} \mathrm{C} \mathrm{yr}^{-1}}^{-1}$ in peri-urban areas. This indicated that decrease in carbon densities was greater in the urban center, but losses in total carbon stocks were greater from peri-urban areas.

\subsection{Terrestrial carbon stocks in the townships of Changzhou}

Average carbon densities in the 42 townships of Changzhou decreased from between 35.34 and $73.27 \mathrm{MgCha}^{-1}$ in 1986 to between 25.73 and $65.44 \mathrm{MgCha}^{-1}$ in 2011 . Total carbon stocks decreased from between 0.01 and $0.98 \mathrm{Tg} C$ in 1986 to between 0.01 and $0.78 \mathrm{TgC}$ in 2011. Carbon densities in the townships in the urban center were smaller than the values in the townships in peri-urban areas because of the larger proportion of land area occupied by urban land (Fig. 2a). Decrease in carbon densities was the greatest in some townships from both the urban center and periurban areas (Fig. 2b). This was due to extensive expansion of urban land in these townships as compared to the others. Total decrease in carbon stocks from the townships in peri-urban areas was greater than decrease from the townships in the urban center, similar to the results from the five municipal districts.

\subsection{Gradient changes in terrestrial carbon stocks along sample transects}

Terrestrial carbon stocks along sample transects increased with increasing distance from the urban center, though fluctuated at some local areas due to complex pattern of urban development in Changzhou. Heavily urbanized area along the west-east transect covered distances of about $7 \mathrm{~km}$ in 1986 and $29 \mathrm{~km}$ in 2011, with carbon stocks averaged $33.32 \mathrm{MgCha}^{-1}$ in 1986 and $27.49 \mathrm{Mg} \mathrm{Cha}^{-1}$ in 2011, smaller than the values in peripheral areas (61.82 $\mathrm{MgCha}^{-1}$ in 1986 and $40.57 \mathrm{MgCha}^{-1}$ in 2011) (Fig. 3a). Heavily urbanized area along the north-south transect covered distances of about $9 \mathrm{~km}$ in 1986 and $25 \mathrm{~km}$ in 2011, with carbon stocks averaged $36.18 \mathrm{MgCha}^{-1}$ in 1986 and $28.06 \mathrm{MgCha}^{-1}$ in 2011 , smaller than the values in peripheral areas along the same transect (72.68 $\mathrm{Mg} \mathrm{Cha}^{-1}$ in 1986 and $60.32 \mathrm{Mg} \mathrm{Cha}^{-1}$ in 2011) (Fig. 3b).

The expansion of urban land created hotspots for losses in carbon stocks in Changzhou. Along the west-east transect, these hotspots were between 5 and $13 \mathrm{~km}$ west of the urban center and between 11 and $20 \mathrm{~km}$ east of the center, with decrease in carbon densities averaged from 1.31 to $1.42 \mathrm{MgCha}^{-1} \mathrm{yr}^{-1}$, greater than the decrease of 0.39 to $0.80 \mathrm{MgC} \mathrm{ha}^{-1} \mathrm{yr}^{-1}$ elsewhere along the transect. Along the north-south transect, these hotspots were 


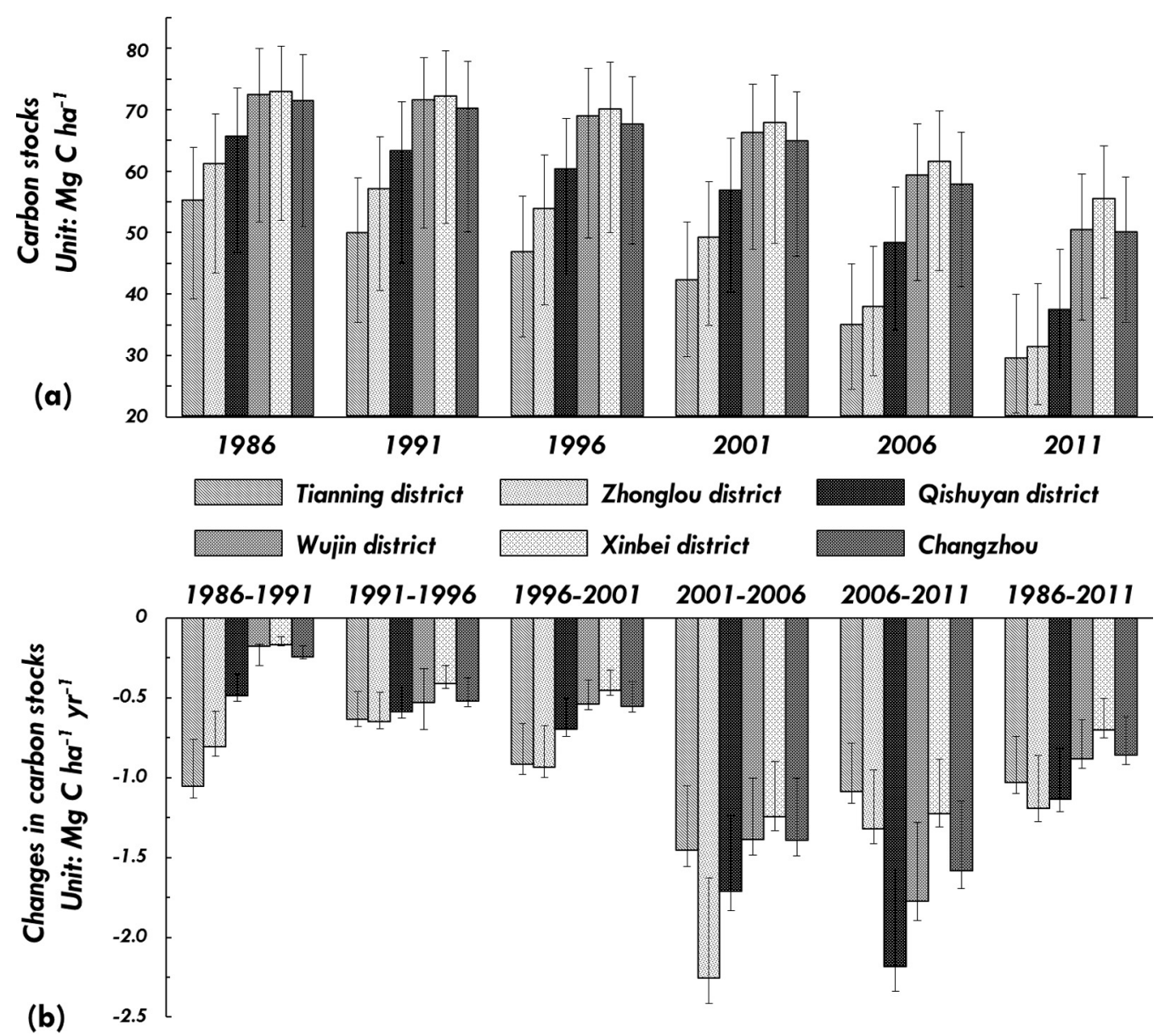

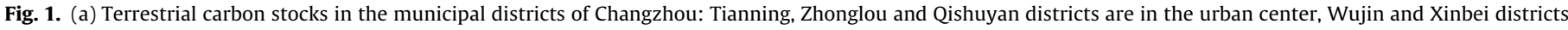

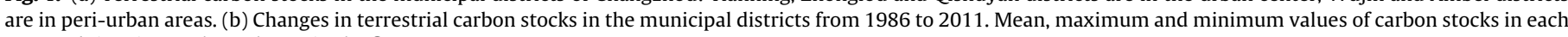
year and time interval are shown in the figure.

between 9 and $16 \mathrm{~km}$ south of the urban center, between 4 and $8 \mathrm{~km}$ north of the center, and between 20 and $21 \mathrm{~km}$ near the Yangtze River. Decrease in carbon densities averaged from 1.61 to $1.77 \mathrm{MgCha}^{-1} \mathrm{yr}^{-1}$ in these areas, greater than the decrease of $0.40-0.42 \mathrm{MgCha}^{-1} \mathrm{yr}^{-1}$ elsewhere along the transect. These results showed that hotspots for losses in carbon stocks covered a greater distance along the west-east transect, but were more segmented along the north-south transect, indicating different patterns of urban development in Changzhou.

\section{Discussion}

\subsection{Comparison of estimated carbon stocks between the urban center and peri-urban areas}

An increase in the overall biomass and soil carbon stocks was observed as distance from the urban center increased across the area. However, a previous study showed that an increase in tree cover on agricultural or other land converted into urban land potentially led to higher rates of carbon uptake and stocks in the urban center (Churkina et al., 2010). This difference from the present study may have resulted, at least in part, from inconsistent definitions of "urban land" (Raciti et al., 2012b). In Changzhou, the urban land was covered by extensive impervious surfaces resulted from clearance of vegetation, removal of the topsoil, and creation of asphalt or concrete pavement. In contrast, various forest patches such as orchards, bamboos, nursery gardens and shrubs were embedded in green open spaces in peri-urban areas, and were rich in biomass and soil carbon stocks (about $75 \%$ of total carbon stocks in 2011). Therefore, biomass and soil carbon in peri-urban areas was the key component of carbon stored in Changzhou.

\subsection{Analysis of primary driving forces of gradient changes in carbon stocks}

Gradient changes in terrestrial carbon stocks in Changzhou from 1986 to 2011 resulted directly from land use and cover change driven by policy-oriented urban planning implemented by the local government. Changzhou has revised its urban master plan five times since the 1980 s to redeploy the development pattern. During the early stage of urbanization in the 1980s and the 1990s, the planners recommended the city to expand toward the north and near the Yangtze River. This focus subsequently caused intensified conversion of land from green open spaces into urban land and caused carbon stocks to decrease by $1.71-1.83 \mathrm{MgCha}^{-1} \mathrm{yr}^{-1}$ in these areas. As urban planning evolved, the expansion of urban land moved toward the east and the south during the 2000s, leading to great changes in land cover and losses in carbon stocks along these axes (Fig. 3a and b). On the whole, urban development in Changzhou followed not only expansion of urban land toward peri-urban areas, but also infilling of empty areas (creation of urban land in formerly vacant land or green open spaces) within the urban center that caused decrease of carbon stocks by 0.28-0.42 $\mathrm{MgCha}^{-1} \mathrm{yr}^{-1}$. 


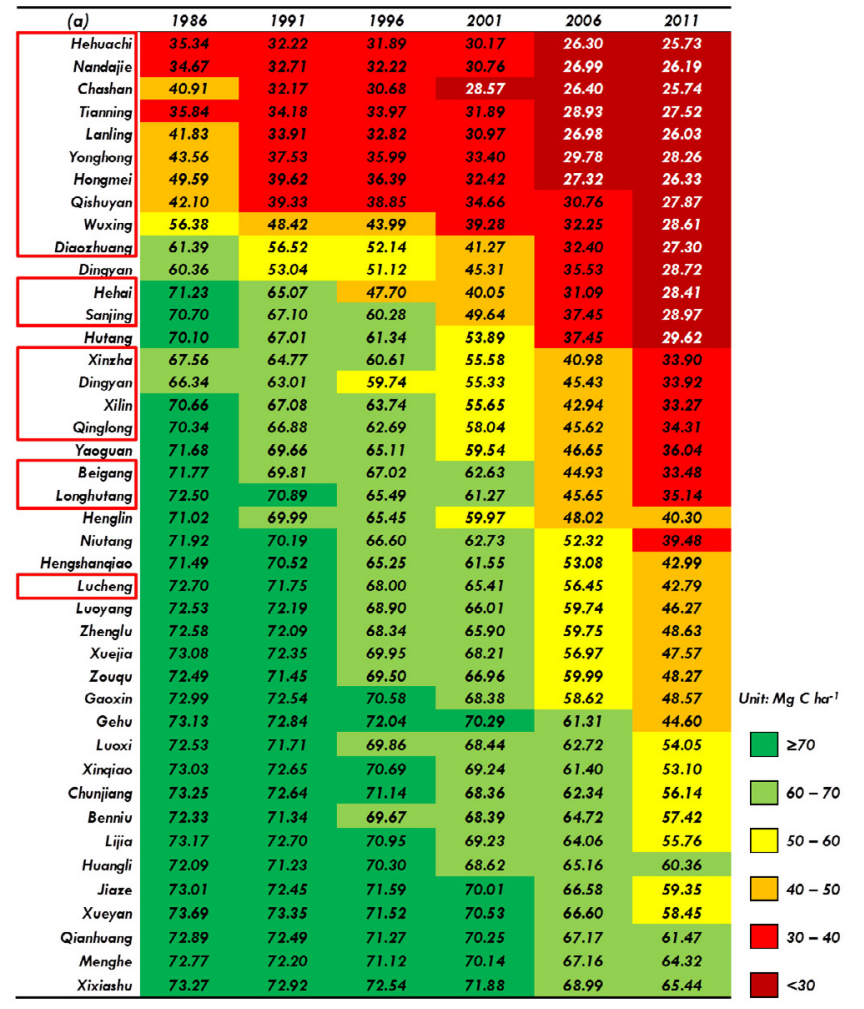

\begin{tabular}{|c|c|c|c|c|c|c|c|}
\hline (b) & 1986-1991 & 1991-1996 & $1996-2001$ & 2001-2006 & $2006-2011$ & $1986-2011$ & \\
\hline Hehail & -1.23 & -3.47 & -1.53 & -1.79 & -0.54 & -1.71 & \\
\hline Saniing & -0.72 & -1.36 & -2.13 & -2.44 & -1.70 & -1.67 & \\
\hline Hutang & -0.62 & -1.13 & -1.49 & -3.29 & -1.57 & -1.62 & \\
\hline Beigang & -0.39 & -0.56 & -0.88 & -3.54 & -2.29 & -1.53 & \\
\hline Xilin & -0.72 & -0.67 & -1.62 & -2.54 & -1.93 & -1.50 & \\
\hline Longhutang & -0.32 & -1.08 & -0.84 & -3.12 & -2.10 & -1.49 & \\
\hline Qinglong & -0.69 & -0.84 & -0.93 & -2.48 & -2.26 & -1.44 & \\
\hline Yaoavan & -0.40 & -0.91 & -1.11 & -2.58 & -2.12 & -1.43 & \\
\hline Diaozhuang & -0.97 & -0.87 & -2.17 & -1.77 & -1.02 & -1.36 & \\
\hline Xinzha & -0.56 & -0.83 & -1.01 & -2.92 & -1.42 & -1.35 & \\
\hline Niutang & -0.35 & -0.72 & -0.77 & -2.08 & -2.57 & -1.30 & \\
\hline Dingyan & -0.67 & -0.65 & -0.88 & -1.98 & -2.30 & -1.30 & \\
\hline Dingyan & -1.47 & -0.38 & -1.16 & -1.96 & -1.36 & -1.27 & \\
\hline Henglin & -0.21 & -0.91 & -1.10 & -2.39 & -1.54 & -1.23 & \\
\hline Lucheng & -0.19 & -0.75 & -0.52 & -1.79 & -2.73 & -1.20 & \\
\hline Gehu & -0.06 & -0.16 & -0.35 & -1.80 & -3.34 & -1.14 & \\
\hline Hengshanqiao & -0.19 & -1.05 & -0.74 & -1.69 & -2.02 & -1.14 & \\
\hline Wuxing & -1.59 & -0.89 & -0.94 & -1.41 & -0.73 & -1.11 & \\
\hline Luoyang & -0.07 & -0.66 & -0.58 & -1.26 & -2.69 & -1.05 & \\
\hline Xuejia & -0.15 & -0.48 & -0.35 & -2.25 & -1.88 & -1.02 & \\
\hline Gaoxin & -0.09 & -0.39 & -0.44 & -1.95 & -2.01 & -0.98 & \\
\hline Zouqu & -0.21 & -0.39 & -0.51 & -1.39 & -2.34 & -0.97 & \\
\hline Zhenglu & -0.10 & -0.75 & -0.49 & -1.23 & -2.22 & -0.96 & \\
\hline Hongmei & -1.99 & -0.65 & -0.79 & -1.02 & -0.20 & -0.93 & \\
\hline Xinqiao & -0.08 & -0.39 & -0.29 & -1.57 & -1.66 & -0.80 & \\
\hline Luoxi & -0.16 & -0.37 & -0.29 & -1.14 & -1.73 & -0.74 & \\
\hline Lijia & -0.09 & -0.35 & -0.34 & -1.03 & -1.66 & -0.70 & \\
\hline Chuniiang & -0.12 & -0.30 & -0.56 & -1.20 & -1.24 & -0.68 & \\
\hline Lanling & -1.59 & -0.22 & -0.37 & -0.80 & -0.19 & -0.63 & \\
\hline Yonghong & -1.21 & -0.31 & -0.52 & -0.73 & -0.30 & -0.61 & Unit: $M g \mathrm{Ch} \boldsymbol{c}^{-1} \mathrm{yr}^{-1}$ \\
\hline Xueyan & -0.07 & -0.37 & -0.20 & -0.79 & -1.63 & -0.61 & \\
\hline Chashan & -1.75 & -0.30 & -0.42 & -0.43 & -0.13 & -0.61 & $(-0.5,0)$ \\
\hline Benniv & -0.20 & -0.33 & -0.26 & -0.73 & -1.46 & -0.60 & \\
\hline Qishuyan & -0.55 & -0.10 & -0.84 & -0.78 & -0.58 & -0.57 & $(-1,-0.5]$ \\
\hline Jiaze & -0.11 & -0.17 & -0.32 & -0.69 & -1.45 & -0.55 & \\
\hline Huangli & -0.17 & -0.19 & -0.33 & -0.69 & -0.96 & -0.47 & $(-1.5,-1]$ \\
\hline Qianhuang & -0.08 & -0.24 & -0.21 & -0.62 & -1.14 & -0.46 & \\
\hline Hehuachi & -0.63 & -0.06 & -0.35 & -0.77 & -0.12 & -0.38 & $(-2,-1.5]$ \\
\hline Nandajie & -0.39 & -0.10 & -0.29 & -0.75 & -0.16 & -0.34 & \\
\hline Menghe & -0.11 & -0.22 & -0.20 & -0.60 & -0.57 & -0.34 & $(-2.5,-2]$ \\
\hline Tianning & -0.33 & -0.04 & -0.42 & -0.59 & -0.28 & -0.33 & \\
\hline Xixieshu & -0.07 & -0.08 & -0.13 & -0.58 & -0.71 & -0.31 & $\leq-2.5$ \\
\hline
\end{tabular}

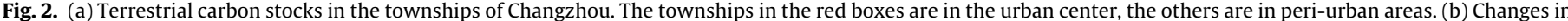

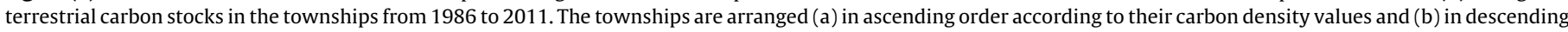
order according to their decrease in carbon densities. (For interpretation of the references to color in this text, the reader is referred to the web version of the article.)

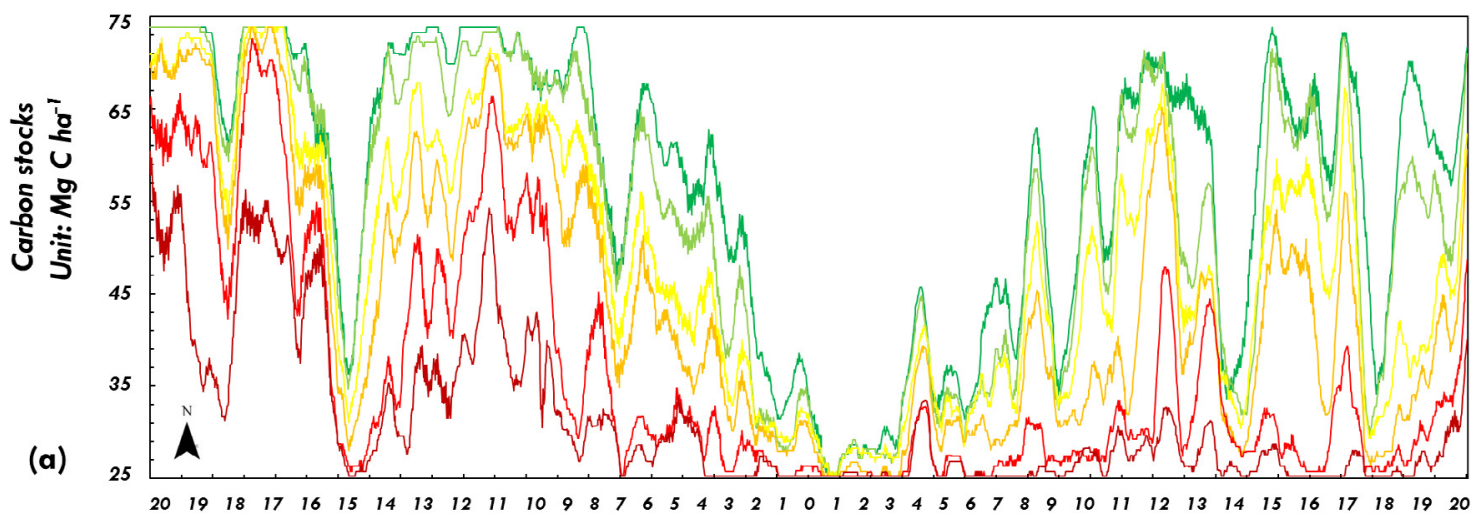

Distance to the urban center

Unit: $\mathbf{k m}$

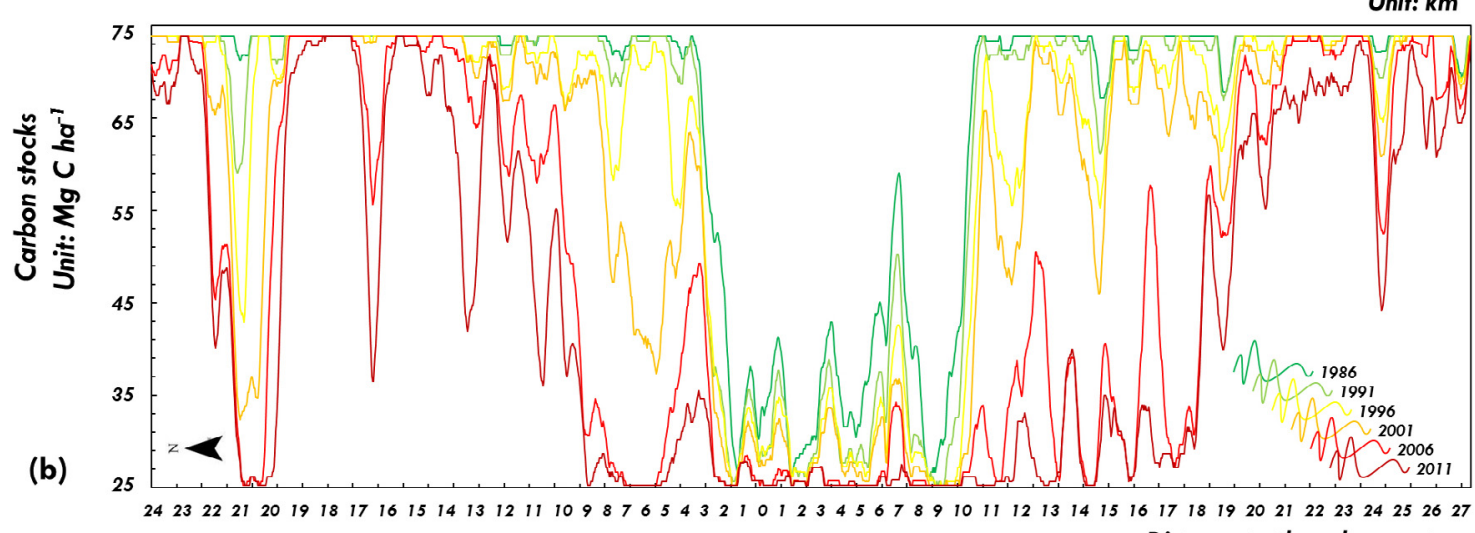

Distance to the urban center

Unit: $\mathbf{k m}$

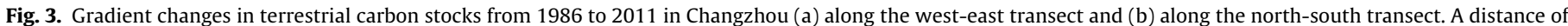
$0 \mathrm{~km}$ represents the geometric mean position of the urban center. 


\subsection{Limitations of the study}

The results of gradient changes in carbon stocks in Changzhou in response to urban land use and cover change depend to a considerable extent on the quality of land cover mapping and accuracy of estimated carbon stocks (Muñoz-Rojas et al., 2011). Davies et al. (2013) noted that biomass estimates in urban areas are potentially highly variable based on the diverse approaches that have been used to estimate carbon stocks and the errors created by extrapolating these estimates to the city-wide scale. Because of these errors, this approach does not provide accurate absolute values but rather provides a relative comparison that is consistent across the urbanization gradient within the study area. In addition, the InVEST model used in this research assumes that none of the land covers in the study area are gaining or losing carbon over time. The only changes in carbon stocks are due to changes from one land cover to another. Any grid cell that does not change its land cover will have a sequestration and loss value of 0 over time. This assumption helps to estimate losses in carbon stocks from urban land use and cover change but needs improvement.

In future research, it will be necessary to partly recover the variety of carbon storage values within coarsely defined land covers by using a more detailed classification of land covers and related estimates of carbon stocks during each time period. It is also possible that the use of wavelet transforms will improve the ability to better identify hotspots for losses in carbon stocks along gradient transects in response to urban land use and cover change. Moreover, variation in a wider range of ecosystem services across the urbanization gradient should be quantified to comprehensively understand the impacts of urban land use and cover change on trade-offs and synergies for provision of multiple ecosystem services.

\subsection{Implications of the results}

In this study, we used the InVEST model to quantify gradient changes in terrestrial carbon stocks in response to urban land use and cover change in Changzhou. We found that carbon stocks increased with increasing distance from the urban center, although this increase was not linear due to the complexity of land covers in the city and of their changes over time in response to policyoriented urban planning, which resulted in expansion of urban land toward peri-urban areas and infilling of empty areas within the urban center. This process caused large decreases in carbon stocks, with clear impacts on regional carbon dynamics and related ecosystem services.

The results suggest potential policy measures to mitigate the effects of urban land use and cover change on carbon stocks for both the urban center and peri-urban areas. For example, it may be possible to replace many of the impervious surfaces such as pavement in urban land with vegetated surfaces, thereby decreasing negative effects of topsoil removal and sealing of the soil surface on accumulation of soil carbon. Legislation should also be implemented to protect green open spaces and forest land and preserve soil carbon stocks in rapidly urbanizing peri-urban areas. Cultivation of vegetation communities such as multi-story forests in the limited urban green spaces is another option to greatly increase urban biomass. Green belts in peri-urban areas provide buffer zones capable of storing additional biomass carbon over time. All these countermeasures should be of vital importance for maintaining urban carbon reservoirs and related ecosystem services essential for climate regulation.

\section{Acknowledgments}

This research was funded by the National Natural Science Foundation of China (Nos. 71273254, 71033005). The datasets used for estimating biomass and soil carbon stocks were from the Environmental and Ecological Science Data Center for West China, National Natural Science Foundation of China (http://westdc.westgis.ac.cn), and from the Renewable Resources and Environmental Science Data Center for West China, Data Sharing Infrastructure of Earth System Science (http://www.geodata.cn). We thank Dr. Geoff Hart, a native English speaker with more than 25 years of experience as a scientific editor, for his constructive suggestions for correcting and polishing the manuscript.

\section{References}

Alberti, M., Hutyra, L., 2009. Detecting carbon signatures of development patterns across a gradient of urbanization: linking observations, models, and scenarios. In: Fifth Urban Research Symposium, Marseilles, France.

Cantarello, E., Newton, A.C., Hill, R.A., 2011. Potential effects of future land-use change on regional carbon stocks in the UK. Environ. Sci. Policy 14, 40-52.

Chan, K.M.A., Shaw, M.R., Cameron, D.R., Underwood, E.C., Daily, G.C., 2006. Conservation planning for ecosystem services. PLoS Biol. 4, 2138-2152.

Chen, S.Q., Chen, B., 2012. Network environ perspective for urban metabolism and carbon emissions: a case study of Vienna, Austria. Environ. Sci. Technol. 46, 4498-4506.

Chen, L., Yang, Z.F., Chen, B., 2013a. Scenario analysis and path selection of lowcarbon transformation in China based on a modified IPAT model. PLoS ONE 8, http://dx.doi.org/10.1371/journal.pone.0077699

Chen, L., Yang, Z.F., Chen, B., 2013b. Decomposition analysis of energy-related industrial $\mathrm{CO}_{2}$ emissions in China. Energies 6, 2319-2337.

Churkina, G., Brown, D.G., Keoleian, G., 2010. Carbon stored in human settlements: the conterminous United States. Global Change Biol. 16, 135-143.

Daily, G.C., Polasky, S., Goldstein, J., Kareiva, P.M., Mooney, H.A., Pejchar, L., Ricketts, T.H., Salzman, J., Shallenberger, R., 2009. Ecosystem services in decision making: time to deliver. Front. Ecol. Environ. 7, 21-28.

Davies, Z.G., Edmondson, J.L., Heinemeyer, A., Leake, J.R., Gaston, K.J., 2011. Mapping an urban ecosystem service: quantifying above-ground carbon storage at a citywide scale. J. Appl. Ecol. 48, 1125-1134.

Davies, Z.G., Dallimer, M., Edmondson, J.L., Leake, J.R., Gaston, K.J., 2013. Identifying potential sources of variability between vegetation carbon estimates for urban areas. Environ. Pollut. 183, 133-142.

Goldstein, J.H., Caldarone, G., Duarte, T.K., Ennaanay, D., Hannahs, N., Mendoza, G., Polasky, S., Wolny, S., Daily, G., 2012. Integrating ecosystem-service tradeoffs into land-use decisions. Proc. Natl. Acad. Sci. U. S. A. 109, 7565-7570.

Hubacek, K., Feng, K.S., Chen, B., 2012. Changing lifestyles towards a low carbon economy: an IPAT analysis for China. Energies 5, 22-31.

Hutyra, L.R., Yoon, B., Alberti, M., 2011a. Terrestrial carbon stocks across a gradient of urbanization: a study of the Seattle, WA region. Global Change Biol. 17, 783-797.

Hutyra, L.R., Yoon, B., Cymerman, J.H., Alberti, M., 2011b. Carbon consequences of land cover change and expansion of urban lands: a case study in the Seattle metropolitan region. Landsc. Urban Plan. 103, 83-93.

Kong, F.H., Nakagoshi, N., 2006. Spatial-temporal gradient analysis of urban green spaces in Jinan, China. Landsc. Urban Plan. 78, 147-164.

Kroll, F., Muller, F., Haase, D., Fohrer, N., 2012. Rural-urban gradient analysis of ecosystem services supply and demand dynamics. Land Use Policy 29, 521-535.

Larondelle, N., Haase, D., 2013. Urban ecosystem services assessment along a rural-urban gradient: a cross-analysis of European cities. Ecol. Indic. 29, 179-190.

Liu, C.F., Li, X.M., 2012. Carbon storage and sequestration by urban forests in Shenyang, China. Urban For. Urban Green. 11, 121-128.

Lorenz, K., Lal, R., 2009. Biogeochemical C and N cycles in urban soils. Environ. Int. $35,1-8$.

Lu, X.L., Kicklighter, D.W., Melillo, J.M., Yang, P., Rosenzweig, B., Vorosmarty, C.J., Gross, B., Stewart, R.J., 2013. A contemporary carbon balance for the northeast region of the United States. Environ. Sci. Technol. 47, 13230-13238.

Muñoz-Rojas, M., De la Rosa, D., Zavala, L.M., Jordán, A., Anaya-Romero, M., 2011. Changes in land cover and vegetation carbon stocks in Andalusia, Southern Spain (1956-2007). Sci. Total Environ. 409, 2796-2806.

Nachtergaele, F., van Velthuizen, H., Verelst, L., 2008. Harmonized World Soil Database. Food and Agriculture Organization of the United Nations, Rome.

Nelson, E., Mendoza, G., Regetz, J., Polasky, S., Tallis, H., Cameron, D.R., Chan, K.M.A., Daily, G.C., Goldstein, J., Kareiva, P.M., Lonsdorf, E., Naidoo, R., Ricketts, T.H., Shaw, M.R., 2009. Modeling multiple ecosystem services, biodiversity conservation, commodity production and tradeoffs at landscape scales. Front. Ecol. Environ. 7, 4-11.

Patak, D.E., Alig, R.J., Fung, A.S., Golubiewski, N.E., Kennedy, C.A., Mcpherson, E.G. Nowak, D.J., Pouyat, R.V., Lankao, P.R., 2006. Urban ecosystems and the North American carbon cycle. Global Change Biol. 12, 2092-2102.

Qiu, J.X., Turner, M.G., 2013. Spatial interactions among ecosystem services in an urbanizing agricultural watershed. Proc. Natl. Acad. Sci. U. S. A. 110, 12149-12154.

Raciti, S.M., Hutyra, L.R., Finzi, A.C., 2012a. Depleted soil carbon and nitrogen pools beneath impervious surfaces. Environ. Pollut. 164, 248-251.

Raciti, S.M., Hutyra, L.R., Rao, P., Finzi, A.C., 2012b. Inconsistent definitions of urban result in different conclusions about the size of urban carbon and nitrogen stocks. Ecol. Appl. 22, 1015-1035. 
Radford, K.G., James, P., 2013. Changes in the value of ecosystem services along a rural-urban gradient: a case study of Greater Manchester, UK. Landsc. Urban Plan. 109, 117-127.

Ren, Y., Wei, X., Wei, X.H., Pan, J.Z., Xie, P.P., Song, X.D., Peng, D., Zhao, J.Z., 2011 Relationship between vegetation carbon storage and urbanization: a case study of Xiamen, China. For. Ecol. Manage. 261, 1214-1223.

Scalenghe, R., Malucelli, F., Ungaro, F., Perazzone, L., Filippi, N., Edwards, A.C., 2011 Influence of 150 years of land use on anthropogenic and natural carbon stocks in Emilia-Romagna region (Italy). Environ. Sci. Technol. 45, 5112-5117.

Seto, K.C., Güneralp, B., Hutyra, L.R., 2012. Global forecasts of urban expansion to 2030 and direct impacts on biodiversity and carbon pools. Proc. Natl. Acad. Sci. U. S. A. $109,16083-16088$.

Strohbach, M.W., Haase, D., 2012. Above-ground carbon storage by urban trees in Leipzig, Germany: analysis of patterns in a European city. Landsc. Urban Plan. 104, 95-104.

Tallis, H.T., Ricketts, T., Guerry, A.D., Wood, S., Sharp, R., 2011. InVEST 2.4.2 User's Guide. The Natural Capital Project, Stanford Wood Institute for the Environment, Stanford, CA.

Turner, B.L., Lambin, E.F., Reenberg, A., 2007. The emergence of land change science for global environmental change and sustainability. Proc. Natl. Acad. Sci. U. S. A. 104, 20666-20671.

Wade, T.G., Wickham, J.D., Zacarelli, N., Riitters, K.H., 2009. A multi-scale method of mapping urban influence. Environ. Model. Softw. 24, 1252-1256.

WDC, 2006. Agricultural photosynthetic-thermal productivity in China (1 km resolution). Renewable Resources and Environmental Science Data Center for West China, Data Sharing Infrastructure of Earth System Science.
Yang, J., Chen, B., 2013. Integrated evaluation of embodied energy, greenhouse gas emission and economic performance of a typical wind farm in China. Renew. Sustain. Energy Rev. 27, 559-568.

Yang, J., Chen, B., 2014a. Emergy analysis of a biogas-linked agricultural system in rural China - a case study in Gongcheng Yao Autonomous County. Appl. Energy $118,173-182$.

Yang, J., Chen, B., 2014b. Carbon footprint estimation of Chinese economic sectors based on a three-tier model. Renew. Sustain. Energy Rev. 29, 499-507.

Yeh, C.T., Huang, S.L., 2009. Investigating spatiotemporal patterns of landscape diversity in response to urbanization. Landsc. Urban Plan. 93, 151-162.

Zhang, C., Tian, H.Q., Chen, G.S., Chappelka, A., Xu, X.F., Ren, W., Hui, D.F., Liu, M.L., Lu, C.Q., Pan, S.F., Lockaby, G., 2012. Impacts of urbanization on carbon balance in terrestrial ecosystems of the Southern United States. Environ. Pollut. 164 89-101.

Zhao, M., Kong, Z.H., Escobedo, F.J., Gao, J., 2010a. Impacts of urban forests on offsetting carbon emissions from industrial energy use in Hangzhou, China. J. Environ. Manage. 91, 807-813.

Zhao, S.Q., Liu, S.G., Li, Z.P., Sohl, T.L., 2010b. Federal land management, carbon sequestration, and climate change in the southeastern U.S.: a case study with Fort Benning. Environ. Sci. Technol. 44, 992-997.

Zhao, D., Li, F., Wang, R.S., Yang, Q.R., Ni, H.S., 2012. Effect of soil sealing on the microbial biomass, $\mathrm{N}$ transformation and related enzyme activities at various depths of soils in urban area of Beijing, China. J. Soils Sedim. 12 519-530. 